\title{
Short Communication: Species confirmation of juvenile cloudy grouper, Epinephelus erythrurus (Valenciennes, 1828), based on a morphologic analysis and partial CO1 gene sequencing
}

\author{
YANTI ARIYANTI ${ }^{1, \boldsymbol{v}}$, ACHMAD FARAJALLAH ${ }^{2, v v}$ \\ ${ }^{1}$ Department of Biology, Institut Teknologi Sumatera. Jl. Terusan Ryacudu, South Lampung 35365, Lampung, Indonesia. Tel/fax. +62-721-80330188, \\ "email: yanti.ariyanti@bi.itera.ac.id \\ ${ }^{2}$ Department of Biology, Faculty of Mathematics and Natural Sciences. Institut Pertanian Bogor. J1. Raya Dramaga, Bogor 16680, West Java, Indonesia \\ Tel./fax.: +62-251-8622833, " "email: achamad@ipb.ac.id
}

Manuscript received: 26 January 2019. Revision accepted: 28 February 2019.

\begin{abstract}
Ariyanti Y, Farajallah A. 2019. Species confirmation of juvenile cloudy grouper, Epinephelus erythrurus (Valenciennes, 1828), based on a morphologic analysis and partial CO1 gene sequencing. Biodiversitas 20: 914-921. The genus Epinephelus is the most species among the genera within the subfamily Epinephelinae. Species identification techniques for groupers, especially in the Epinephelus, are commonly based on color patterns and a suite of morphological characters, including body shape and the size and number of fins, scales and gill rakers. In some species, juveniles are morphologically distinct from adults of the same species, making morphological identification highly problematic. This present work will provide some morphological description or variations of juveniles that have been identified as Epinephelus erythrurus based on CO1 sequences. Further, the present study demonstrates that a molecular genetic technique, based on partial sequencing of the mitochondrial CO1 gene, may be used for the rapid species confirmation of every developmental stage and phase of an organism (juvenile E. erythrurus). Two DNA sequences of E. erythrurus from the Pangandaran District (743'8.31"S 108 30'11.59”E) have been submitted to GenBank under accession numbers KP998441 and KP998442.
\end{abstract}

Keywords: Epinephelus erythrurus, $\mathrm{CO} 1$, confirmation, grouper, juveniles

\section{INTRODUCTION}

The Subfamily Epinephelinae is a group of carnivorous marine fishes that belongs to the Family Serranidae. This group comprises about 159 species in 15 genera, commonly known as groupers, rockcods, hinds, and seabasses (Heemstra and Randall 1993). These commercially important fishes are bottom-associated which is found in tropical and subtropical waters. Most species occupy coral reefs, but some inhabit estuaries or on rocky reefs. Grouper has potential economic value in fisheries. However, the classification and their evolutionary relationship were often constrained by the incredible number of species, wide distribution, and lack of morphological key that it is used in classification. The genus Epinephelus is the most species among the genera within the subfamily Epinephelinae. The genus is represented in tropical and subtropical latitudes of all three major oceans. Epinephelus species are among the most important commercial fishes in global tropical fisheries (Carpenter and Niem 1999). However, many species within Epinephelus lack morphological specializations that are particularly used to identify individual species in the field.

Identification techniques for grouper species, especially Epinephelus, are commonly based on their color patterns and a suite of morphological characters, including body shape and the size and number of fins, scales and gill rakers (Craig et al. 2001; Heemstra and Randall 1993). The color pattern is usually distinctive enough to identify large adult groupers at the species level, but intra-specific variations in color pattern exist for each species (Heemstra and Randall 1993). Moreover, interspecific hybridizations are found among many grouper species (Ding et al. 2006). This has rendered to a great deal of taxonomic confusion within the genus.

In many cases, fishes, and especially their diverse developmental stages, are difficult to identify using morphological characters (Teletchea 2009). For example, the juveniles of some species of grouper are completely morphologically distinct from adults of the same species, making morphological identification extremely difficult (Govindaraju and Jayasankar 2004). Molecular genetic techniques, such as DNA sequencing of genes are known to complement morphological identification (Hebert et al. 2003). For example, a small sequence of the mitochondrial cytochrome oxidase $c$ subunit 1 (CO1) gene has been used in rapid analyses for commercial purposes, especially for the confirmation of fish species (Ward et al. 2005; Barber and Boyce 2006; Wong and Hanner 2008; Sachithanandam et al. 2012).

This present work will provide some morphological description or variations of juveniles that have been identified as Epinephelus erythrurus based on CO1 
sequences. Partial of cytochrome oxidase c subunit 1 (CO1) gene were used as a molecular marker in order to confirm two E. erythrurus juveniles. We sought to show that molecular genetic techniques can be used to complement the morphological identification of juveniles of E. erythrurus. This species is very rarely caught so that the reports of the existence of this species is still lacking. Therefore, this species is listed as Least Concern (LC) status on the IUCN Red List. Another important result from this research is that the CO1 sequence for Indonesian $E$. erythrurus, which was previously absent from GenBank, is presented here for the first time.

\section{MATERIALS AND METHODS}

\section{Study area}

Samples of fish belonging to the family Serranidae were collected from fisherman at Bojongsalawe Beach (743'8.31"S 108 30'11.59"E) in the Pangandaran District of West Java, Indonesia (Figure 1). Phenotypic characterization was conducted using the FAO species catalog of groupers of the world, and samples were stored in formalin. A portion of the dorsal muscle tissue was stored in $95 \%$ alcohol for the molecular genetics study.

\section{DNA extraction and PCR}

Total DNA was extracted from $0.30 \mathrm{~g}$ of ethanolpreserved muscle tissue using a DNA Extraction Kit for animal tissue (Geneaid Biotech Ltd., New Taipei City, Taiwan), following the manufacturer's protocol. Approximately 650-655 bp were amplified from the 5' region of the $\mathrm{CO} 1$ gene using combinations of the primers AF282 and AF283 (modification of Ivanova 2007; FISHBOL, http://www.fishbol.org).

The $25 \mu \mathrm{L}$ PCR mixes included $12.5 \mu \mathrm{L}$ of $2 \mathrm{X}$ ReadyMix Green GoTaq ${ }^{\circledR}$ DNA Polymerase mix (0.05 $\mathrm{U} / \mu \mathrm{L}, 3 \mathrm{mM} \mathrm{Mg}^{2+}$,and0.4 mM each dNTP), $1 \mu \mathrm{L}$ of each primer at a $10 \mu \mathrm{M} / \mu 1$ concentration, $1 \mu \mathrm{L}$ of template DNA and $9.5 \mu \mathrm{L}$ of nuclease-free water. The thermal regime consisted of an initial step of $2 \mathrm{~min}$ at $94{ }^{\circ} \mathrm{C}$ followed by 35 cycles of $0.5 \mathrm{~min}$ at $94{ }^{\circ} \mathrm{C}, 0.5 \mathrm{~min}$ at $56{ }^{\circ} \mathrm{C}$, and $1 \mathrm{~min}$ at $72{ }^{\circ} \mathrm{C}$, followed in turn by $7 \mathrm{~min}$ at $72{ }^{\circ} \mathrm{C}$, with the samples then held at $4.0{ }^{\circ} \mathrm{C}$ in a Takara ${ }^{\mathrm{TM}}$ thermocycler (Otsu, Japan). Verification of the $2 \mu \mathrm{L}$ amplicon was performed using a $6 \%$ polyacrylamide gel electrophoresis, ran at a voltage of $200 \mathrm{~V}$ for $40 \mathrm{~min}$. Visualization was facilitated by silver staining (Byun et al. 2009).

All amplicons were sequenced commercially following the manufacturer's protocol. The DNA sequences were proofread, edited and assembled using MEGA6 (Tamura et al. 2013) and BioEdit (Hall 1999). A Kimura 2-parameter metric was employed for sequence comparisons (Kimura 1980), including genetic distance calculations and to generate neighbor-joining trees based on the $\mathrm{CO} 1$ region, with node frequencies calculated based on 1000 bootstrap replicates.

\section{RESULTS AND DISCUSSION}

\section{Diagnostic features}

Morphometric comparisons of E. erythrurus with the existing literature are shown in Table 1. Specimen voucher K7_PGR has a body depth of 2.74 in standard length (SL) and a head length of 2.37 in SL, with SL and the total length of $107 \mathrm{~mm}$ and $135 \mathrm{~mm}$, respectively. Specimen voucher K8_PGR has a body depth of 2.58 in SL and a head length of 2.33 in SL, with SL and the total length of $93 \mathrm{~mm}$ and $125 \mathrm{~mm}$, respectively. Both specimens have dorsal fins with XI spines and 16 rays, anal fins with III spines and 8 rays, pectoral fins with 19 rays, rounded caudal fins, and a dark gray body.

\section{CO1-based analysis}

The two E. erythrurus DNA sequences were submitted individually to GenBank under accession numbers KP998441 for the K7 PGR specimen voucher and KP998442 for the K8 PGR specimen voucher (Table 3). Out of the 640-651-bp basic taxonomic sequence length, we were able to obtain 548bp. BLAST searches using the two sequences indicated only nine sequences of $E$. erythrurus from Thailand and Malaysia in GenBank. The query coverage was $91 \%$, and the maximum identity was 99-100\% with existing E. erythrurus sequences in GenBank. Based on the partial CO1 sequences, a molecular phylogenetic tree was constructed using the neighborjoining method (Kimura 2-parameter). The bootstrap confidence values of the nodes are indicated above each branch. Interestingly, Thai E. erythrurus had the smallest number of nucleotides (420 bp). We constructed two phylogenetic trees, with and without the Thai E. erythrurus sequences (Figures 2 and 3). Intra-and inter-specific genetic distances are shown in Table 2.

Figure 2 shows a phylogenetic tree without the Thai $E$. erythrurus sequence. The two sequences in the present study were grouped with similar Malaysian E. erythrurus sequences. Some E. coeruleopunctatus sequences formed a sister group with E. erythrurus, while other sequences formed a separate clade. Furthermore, the intra-specific genetic distance of E. erythrurus ranged from 0.000 to 0.014 with the same species from other countries, while the inter-specific genetic distance between $E$. erythrurus and $E$. coeruleopunctatus ranged from 0.022 to 0.074 . However, the phylogenetic tree with the first barcode for Thai $E$. erythrurus (JQ268576) (Figure 3) formed a species complex group with some E. coeruleopunctatus, distinct from the other separated clades of E.erythrurus and E.coeruleopunctatus. This suggests that E. erythrurus and E. coeruleopunctatus are not monophyletic. The genetic distance between pairs of Indonesian E. erythrurus and Thai E. erythrurus ranged from 0.066 to 0.068 (Table 2), suggesting two main genotypes of this species. Based on the two phylogenetic trees, both of our samples were grouped with the Indonesian and Malaysian E. erythrurus that possessed a genotype different from the Thai $E$. erythrurus. 


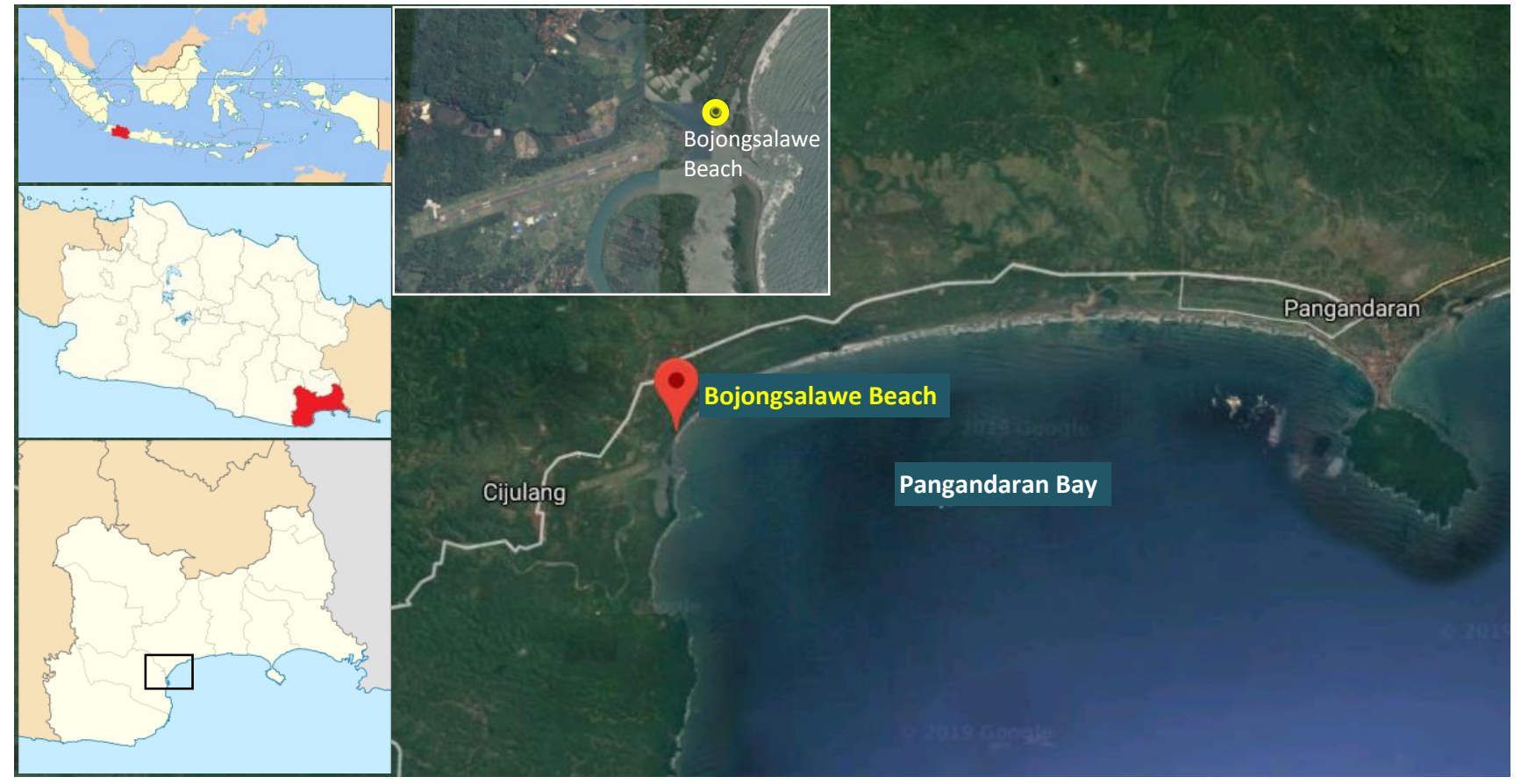

Figure 1. Location of Bojongsalawe Beach (743'8.31"S 108³0'11.59”'E) in the Pangandaran District of West Java, Indonesia

Table 1. Morphometric comparison of the E. erythrurus specimens in the present study with those in the literature

\begin{tabular}{|c|c|c|c|c|c|}
\hline $\begin{array}{l}\text { Morphometric } \\
\text { characters }\end{array}$ & $\begin{array}{c}\text { E. erythrurus } \\
\text { (KP998441 } \\
\text { [K7_PGR]) } \\
\text { (Present study) } \\
\end{array}$ & $\begin{array}{c}\text { E. erythrurus } \\
\text { (KP998442 } \\
\text { [K8_PGR]) } \\
\text { (Present study) } \\
\end{array}$ & $\begin{array}{c}\text { E. erythrurus } \\
\text { (Hemstra and Randall } \\
\text { 1993) }\end{array}$ & $\begin{array}{l}\text { E. erythrurus } \\
\text { (Carpenter and } \\
\text { Niem 1998) }\end{array}$ & $\begin{array}{c}\text { E. erythrurus } \\
\text { (Allen et al. 2003) }\end{array}$ \\
\hline$\overline{\text { Body depth }}$ & 2.74 times in SL & 2.58 times in SL & 2.8-3.2 times in SL & \multirow{12}{*}{$430 \mathrm{~mm}$} & \multirow{11}{*}{ To $430 \mathrm{~mm}$} \\
\hline Standard length & $107 \mathrm{~mm}$ & $93 \mathrm{~mm}$ & $110-280 \mathrm{~mm}$ & & \\
\hline Total length & $135 \mathrm{~mm}$ & $125 \mathrm{~mm}$ & - & & \\
\hline Head length & 2.37 times in SL & 2.33 times in SL & 2.4-2.7 times in SL & & \\
\hline Dorsal fin & $\mathrm{XI}$ & XI & XI & & \\
\hline Dorsal rays & 16 & 16 & 15 or 17 & & \\
\hline Anal spines & III & III & III & & \\
\hline Anal rays & 8 & 8 & 8 & & \\
\hline Caudal fin & Rounded & Rounded & Rounded & & \\
\hline Pectoral fins & 19 & 19 & $17-19$ & & \\
\hline Lateral scales series & 97 & 92 & $92-107$ & & \\
\hline Colour & Dark gray & Dark gray & $\begin{array}{l}\text { Olive to reddish brown, } \\
\text { usually with irregular pale } \\
\text { spots and blotches that join } \\
\text { randomly to form an } \\
\text { irregular dark reticulum of } \\
\text { the background color. Some } \\
\text { specimens, especially the } \\
\text { larger ones, nearly uniform } \\
\text { brown or with the pale } \\
\text { blotches on the body only } \\
\text { faintly visible }\end{array}$ & & $\begin{array}{l}\text { Dark gray with } \\
\text { irregular pale spots } \\
\text { and randomly joined } \\
\text { to form a maze-like } \\
\text { pattern }\end{array}$ \\
\hline Geographical & Bojongsalawe & Bojongsalawe & Pakistan, India, Laccadive & Pakistan, India, & Pakistan, Laccadive \\
\hline distribution & $\begin{array}{l}\text { Beach, } \\
\text { Pangandaran } \\
\text { District, } \\
\text { Indonesia }\end{array}$ & $\begin{array}{l}\text { Beach, } \\
\text { Pangandaran } \\
\text { District, } \\
\text { Indonesia }\end{array}$ & $\begin{array}{l}\text { Island, Sri Lanka, Gulf of } \\
\text { Thailand, Indonesia, } \\
\text { Singapore, and Borneo }\end{array}$ & $\begin{array}{l}\text { Laccadive Is. Sri } \\
\text { Lanka, Gulf of } \\
\text { Thailand, Indonesia, } \\
\text { and Singapore }\end{array}$ & $\begin{array}{l}\text { Is. off India to } \\
\text { Malaysian Peninsula } \\
\text { and W. Indonesia }\end{array}$ \\
\hline Habitat & & & $\begin{array}{l}\text { Harbors and estuaries with } \\
\text { muddy or silty-sand } \\
\text { bottoms }\end{array}$ & $\begin{array}{l}\text { In harbors and } \\
\text { estuaries with muddy } \\
\text { or silty-sand bottoms }\end{array}$ & $\begin{array}{l}\text { Solitary, turbid } \\
\text { harbors and estuaries } \\
\text { with muddy or silty- } \\
\text { sand bottoms }\end{array}$ \\
\hline
\end{tabular}


Table 3. DNA Sequences details of E. erythrurus in GenBank file version

\begin{tabular}{|c|c|c|}
\hline Definition locus & Seq7 Epinephelus erythrurus CO1 gene CDS & Seq8 Epinephelus erythrurus CO1 gene CDS \\
\hline Accession number & KP998441 & KP998442 \\
\hline Submitted date & VRT 20-Mar-2015 & VRT 20-Mar-2015 \\
\hline Classification & $\begin{array}{l}\text { Eukaryota; Metazoa; Chordata; Craniata; } \\
\text { Vertebrata; Euteleostomi; Actinopterygii; } \\
\text { Neopterygii; Teleostei; Euteleostei; Neoteleostei; } \\
\text { Acanthomorpha; Eupercaria; Perciformes; } \\
\text { Serranoidei; Serranidae; Epinephelinae; } \\
\text { Epinephelini; Epinephelus }\end{array}$ & $\begin{array}{l}\text { Eukaryota; Metazoa; Chordata; Craniata; Vertebrata; } \\
\text { Euteleostomi; Actinopterygii; Neopterygii; Teleostei; } \\
\text { Euteleostei; Neoteleostei; Acanthomorpha; } \\
\text { Eupercaria; Perciformes; Serranoidei; Serranidae; } \\
\text { Epinephelinae; Epinephelini; Epinephelus }\end{array}$ \\
\hline Alignment of partial & $>$ Seq7 & $>$ Seq 8 \\
\hline Sequences of the $\mathrm{CO} 1$ & AACCACAAAGACATCGGCACCCTTTATCTTGTATT & AACCACAAAGACATCGGCACCCTTTATCTTGTATTT \\
\hline Gene & $\begin{array}{l}\text { TGGTGCCTGAGCCGGTATAGTAGGAACGGCTCTCA } \\
\text { GCCTGCTTATTCGAGCCGAGCTTAGCCAACCAGGG } \\
\text { GCTCTACTAGGTGAGATCAGATCTATAATGTAAT } \\
\text { TGTTACAGCACACGCTTTTGTAATAATCTTTTTA } \\
\text { TAGTAATACCAATCATGATTGGTGGCTTTGGAAAC } \\
\text { TGACTCATCCCGCTAATAATTGGTGCCCCAGATAT } \\
\text { AGCATTCCCTCGAATAAATAATATGAGCTTCTGAC } \\
\text { TTCTCCCCCCATCCTTCTTACTTCTTCTCGCTTCT } \\
\text { TCTGGAGTAGAAGCCGGTGCTGGTACTGGCTGAAC } \\
\text { GGTCTACCCACCCCTAGCCGGAACCTAGCCCATG } \\
\text { CAGGTGCATCTGTAGACTTAACTATCTTCTCATTA } \\
\text { CATTTAGCAGGATCTCATCAATTCTAGGTGCAAT } \\
\text { CAATTTATCACAACTATTATTAATATGAAACCC } \\
\text { CAGCTATCTCCCAATACCAAACACCTTTATTTGTA } \\
\text { TGAGCGGTACTAATTACAGCAGTGCTCCTGCTCCT } \\
\text { CTCCCTTCCTGTTCTCGCCGCCGGCATTACAATAC } \\
\text { TACTTACAGATCGCAACCTTAACACCACTTTCTTT } \\
\text { GACCCCGCT }\end{array}$ & $\begin{array}{l}\text { GGTGCCTGAGCCGGTATAGTAGGAACAGCTCTCAGC } \\
\text { CTGCTTATTCGAGCCGAGCTTAGCCAACCAGGGGCT } \\
\text { CTACTAGGTGCGATCAGATCTATAATGTAATGTT } \\
\text { ACAGCACACGCTTTTGTAATAATCTTTTTATAGTA } \\
\text { ATACCAATCATGATTGGTGGCTTTGGAAACTGATC } \\
\text { ATCCCGCTAATAATTGTGCCCCAGATATAGCATTC } \\
\text { CCTCGAATAAATAATATGAGCTTCTGACTTCTCCCC } \\
\text { CCATCCTTCTTACTTCTTCTCGCTTCTTCTGGAGTA } \\
\text { GAAGCCGGTGCTGGTACTGGCTGAACGGTCTACCCA } \\
\text { CCCCTAGCCGGAAACCTAGCCCATGCAGGTGCATCT } \\
\text { GTAGACTTAACTATCTTCTCATTACATTTAGCAGGA } \\
\text { ATCTCATCAATCTAGGTGCAATCAATTTATCACA } \\
\text { ACTATTATTAATATGAAACCCCAGCTATCTCCCAA } \\
\text { TACCAAACACCTTTATTTGTATGAGCGGTACTAATT } \\
\text { ACAGCAGTGCTCCTGCTCCTCTCCCTTCCTGTTCTC } \\
\text { GCCGCCGGCATTACAATACTACTTACAGATCGCAAC } \\
\text { CTTAACACCACTTTCTTTGACCCCGCTGGAGGGGAG } \\
\text { ACC }\end{array}$ \\
\hline $\begin{array}{l}\text { Translated protein } \\
\text { sequence }\end{array}$ & $\begin{array}{l}\text { NHKDIGTLYLVFGAWAGMVGTALSLLIRAELSQPG } \\
\text { ALLGDDQIYNVIVTAHAFVMIFFMVMPIMIGGFGN } \\
\text { WLIPLMIGAPDMAFPRMNNMSFWLLPPSFLLLLAS } \\
\text { SGVEAGAGTGWTVYPPLAGNLAHAGASVDLTIFSL } \\
\text { HLAGISS ILGAINFITTI INMKPPAISQYQTPLFV } \\
\text { WAVLITAVLLLLSLPVLAAGITMLLTDRNLNTTFF } \\
\text { DPA }\end{array}$ & $\begin{array}{l}\text { NHKDIGTLYLVFGAWAGMVGTALSLLIRAELSQPGA } \\
\text { LLGDDQIYNVIVTAHAFVMIFFMVMP IMIGGFGNWL } \\
\text { IPLMIGAPDMAFPRMNNMSFWLLPPSFLLLLASSGV } \\
\text { EAGAGTGWTVYPPLAGNLAHAGASVDLTIFSLHLAG } \\
\text { ISS I LGA INF ITTI INMKPPAISQYQTPLFVWAVLI } \\
\text { TAVLLLLSLPVLAAGITMLLTDRNLNTTFFDPAGGE }\end{array}$ \\
\hline
\end{tabular}

\section{Discussion}

We diagnosed both of our specimens as juvenile $E$. erythrurus based on the following criteria shown in Table 1. According to Carpenter and Niem (1999), females of this species mature at $15 \mathrm{~cm}$ of the SL. Also, the adult color pattern of this species is usually irregular pale spots and blotches that join randomly to form an irregular dark reticulum of the background color. Some specimens, especially larger ones, are nearly uniform brown or have pale blotches on the body that are only faintly visible (Randall and Heemstra 1993).

According to Noitokr et al. (2013), the top ten BLAST results in GenBank showed that the sequences of $E$. erythrurus were highly similar to those of Epinephelus coeruleopunctatus. In the current classification, an adult of E. coeruleopunctatus has XI dorsal spines with the longest on the third or fourth spine with its length of 2.7 to 3.6 times in head length, and 15 to 17 rays; anal fin with III spines and 8 rays; large and fleshy pectoral fins, with 17-19 rays; rounded caudal fin. The color is brownish grey; the body is covered with small pale spots overlain with large pale blotches; oblique black saddle on the rear half of peduncle; 4 to 5 indistinct black blotches at the base of dorsal fin, a prominent black streak on the maxillary groove. Meanwhile, juveniles (less than $20 \mathrm{~cm}$ standard length) are dark grey to black, covered with prominent pupil-size white spots and smaller white dots (Randall and Heemstra 1993). Based on the statement of Hebert et al. (2003), the CO1 gene sequence can delimit species when intraspecific genetic divergences are greater than $2 \%$ so that we suppose the specimens from Thailand are not $E$. erythrurus. It is probably due to a juvenile of $E$. coeruleopunctatus could not be easily differentiated from juvenile of E. erythrurus. Thus, it might be caused by misidentification between both of them. These COI sequences could provide genetic data to confirm and compare molecular and morphological traits. In case, the cloudy grouper has extremely different phenotypic traits between the juvenile and adult individual in same species, and it still becomes a serious problem on species determining particularly on its cloudy grouper specimen. 
Table 2. Genetic distance of CO1 sequences from Indonesian E. erythrurus and reference sequences from GenBank (below the diagonal), with standard error estimates (above the diagonal)

\begin{tabular}{|c|c|c|c|c|c|c|c|c|c|c|c|c|c|c|c|c|c|c|c|c|}
\hline Acc & 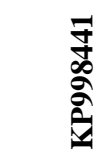 & 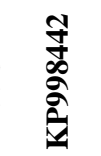 & 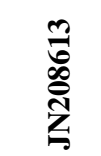 & 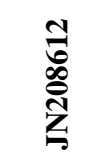 & 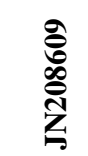 & 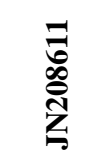 & 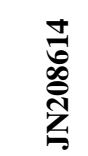 & 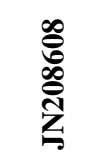 & 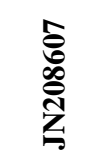 & 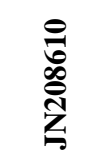 & 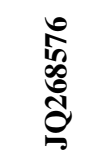 & 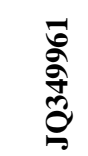 & 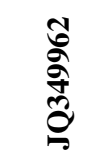 & 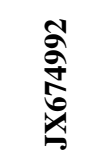 & 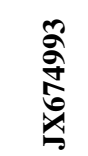 & 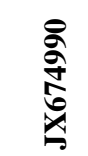 & $\begin{array}{l}\bar{a} \\
\frac{\hat{d}}{b} \\
\stackrel{x}{a}\end{array}$ & 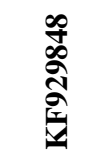 & 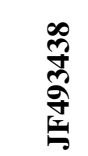 & 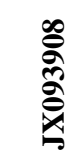 \\
\hline $41 F$ & & 002 & .002 & 000 & 005 & 006 & $\overline{006}$ & 002 & 002 & 002 & 013 & .014 & .013 & 008 & 008 & .008 & 008 & .013 & .013 & .012 \\
\hline KP9 & 002 & & 03 & 02 & 05 & 05 & 05 & 00 & 03 & 03 & 013 & 014 & 012 & 007 & 007 & 007 & 007 & 012 & 012 & .012 \\
\hline L. & 0.002 & 0.005 & & .002 & 006 & 006 & 006 & 003 & 0.000 & 000 & 013 & .014 & 013 & 0.008 & .008 & .008 & 008 & .013 & 013 & .012 \\
\hline & 000 & 0.002 & 0.002 & & 0.005 & 0.006 & .006 & 002 & 0.002 & 002 & 0.013 & .014 & 013 & 0.008 & .008 & 0.008 & 0.008 & .013 & 0.013 & .012 \\
\hline & & 010 & 0.014 & 0.012 & & 0.002 & .002 & 005 & 0.006 & .006 & 0.013 & .014 & .012 & 0.005 & .005 & .005 & .005 & .012 & 0.012 & .011 \\
\hline & & 012 & 0.017 & 0.014 & 002 & & 0.000 & 005 & 0.006 & 006 & 013 & .014 & 012 & 0.006 & .006 & .006 & 006 & 0.012 & 012 & .012 \\
\hline & & 012 & 0.017 & .014 & 0.002 & 0.000 & & 0.005 & 0.006 & .006 & 013 & .014 & 12 & 0.006 & .006 & .006 & 0.006 & 012 & & .012 \\
\hline & & 000 & 0.005 & .002 & 010 & 0.012 & 0.012 & & 0.003 & 003 & 13 & .014 & 12 & 007 & 007 & 007 & .007 & 012 & & 012 \\
\hline & & 5 & 00 & 02 & 014 & 0.017 & 0.017 & 0.005 & & 0.000 & 0.013 & 14 & 13 & 08 & 08 & 08 & 08 & 0.013 & 13 & .012 \\
\hline & & 005 & 0.000 & 002 & 014 & 0.017 & 0.017 & 0.005 & 0.000 & & 0.013 & 0.014 & 13 & 0.008 & 08 & 0.008 & 008 & 0.013 & 13 & 0.012 \\
\hline & 58 & 066 & 0.071 & .068 & 066 & 0.068 & 0.068 & 0.066 & 0.071 & 0.071 & & 0.007 & 0.005 & 0.011 & 011 & 0.011 & 11 & 0.005 & 0.004 & 0.011 \\
\hline & 74 & 071 & 0.076 & 0.074 & 071 & 0.074 & 0.074 & 0.071 & 0.076 & 0.076 & 0.019 & & 0.006 & 0.012 & .012 & 0.012 & 012 & 0.007 & 0.005 & 0.011 \\
\hline & 33 & 061 & 0.066 & 063 & 058 & 0.061 & .061 & 0.061 & 0.066 & 066 & 0.010 & 0.014 & & 0.011 & 011 & 0.011 & 11 & .005 & 0.002 & 0.010 \\
\hline & 24 & 022 & 0.027 & .024 & 012 & 0.014 & .014 & 022 & 0.027 & 0.027 & 0.052 & 0.057 & 0.045 & & 0.000 & 0.000 & 00 & 0.011 & 011 & 0.012 \\
\hline & 24 & 022 & 0.027 & .024 & 012 & 0.014 & .014 & 0.022 & 0.027 & 0.027 & 0.052 & 0.057 & 0.045 & 0.000 & & 0.000 & 0.000 & 0.011 & 0.011 & 0.012 \\
\hline & 24 & 022 & 0.027 & .024 & 012 & 0.014 & 0.014 & 0.022 & 0.027 & 0.027 & 0.052 & 0.057 & 0.045 & 0.000 & 0.000 & & 0.000 & 0.011 & 0.011 & 0.012 \\
\hline & 24 & 022 & 0.027 & .024 & 012 & 0.014 & .014 & 022 & 0.027 & 027 & 0.052 & 0.057 & 0.045 & 0.000 & 0.000 & 0.000 & & .011 & 0.011 & 0.012 \\
\hline & & 061 & 0.066 & 063 & 061 & 0.063 & 063 & & 0.066 & .066 & 0.012 & 019 & 0.010 & 0.053 & .053 & 0.053 & 0.053 & & 0.004 & 0.011 \\
\hline & & 058 & 0.063 & 061 & 10 & 0.061 & 0.061 & 0.058 & 0.063 & 063 & 0.007 & .012 & 0.002 & 0.045 & 0.045 & 0.045 & 0.045 & 0.007 & & 0.010 \\
\hline E. corallicola & 0.060 & 0.060 & 0.063 & 0.060 & 0.055 & 0.058 & 0.058 & 0.060 & 0.063 & 0.063 & 0.055 & 0.060 & 0.047 & 0.058 & 0.058 & 0.058 & 0.058 & 0.055 & 0.047 & \\
\hline
\end{tabular}




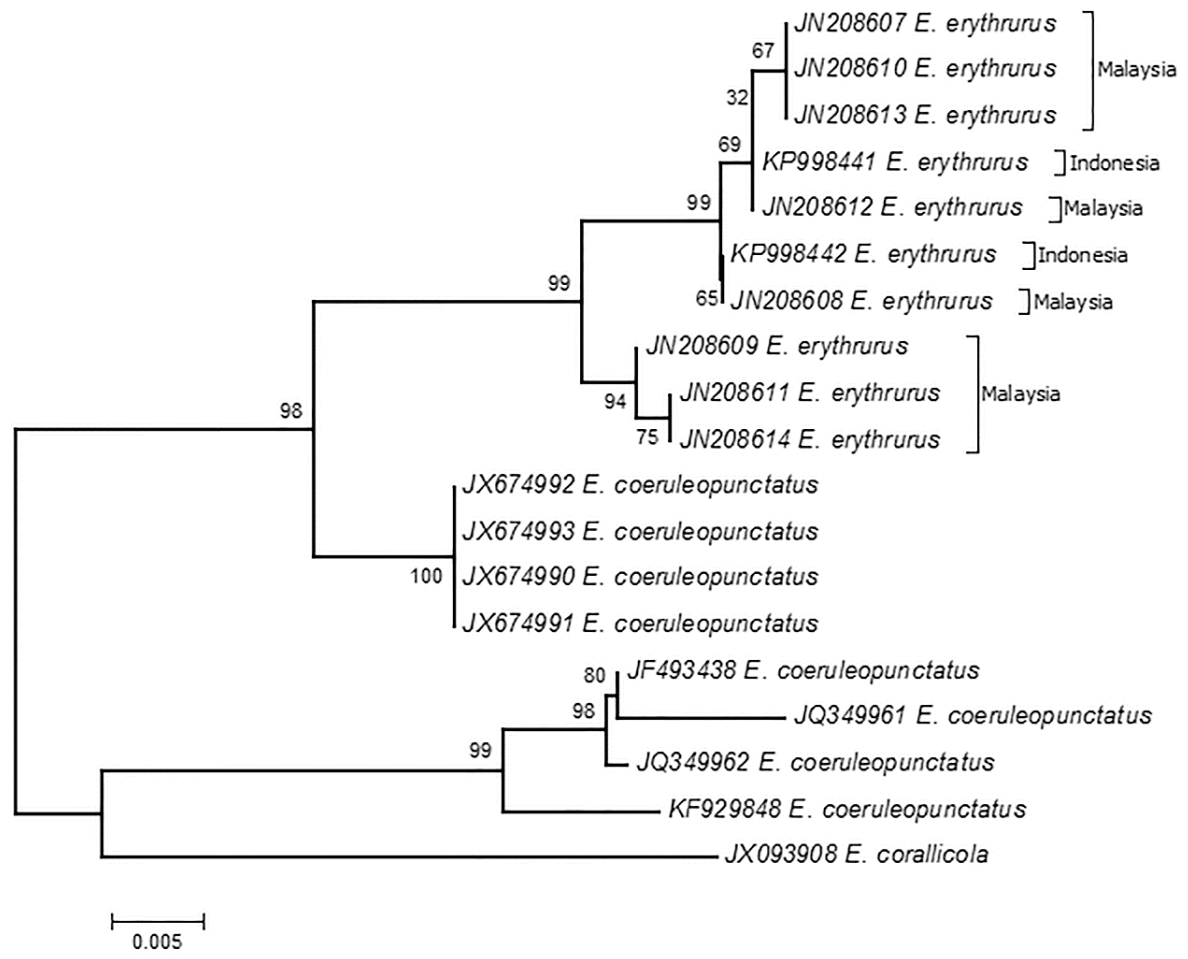

Figure 2. Neighbor-joining tree based on the CO1 nucleotide sequences of the E. erythrurus specimens analyzed in the present work and of species from GenBank (without Thai E. erythrurus). The numbers at the nodes indicate bootstrap values for 1000 replicates

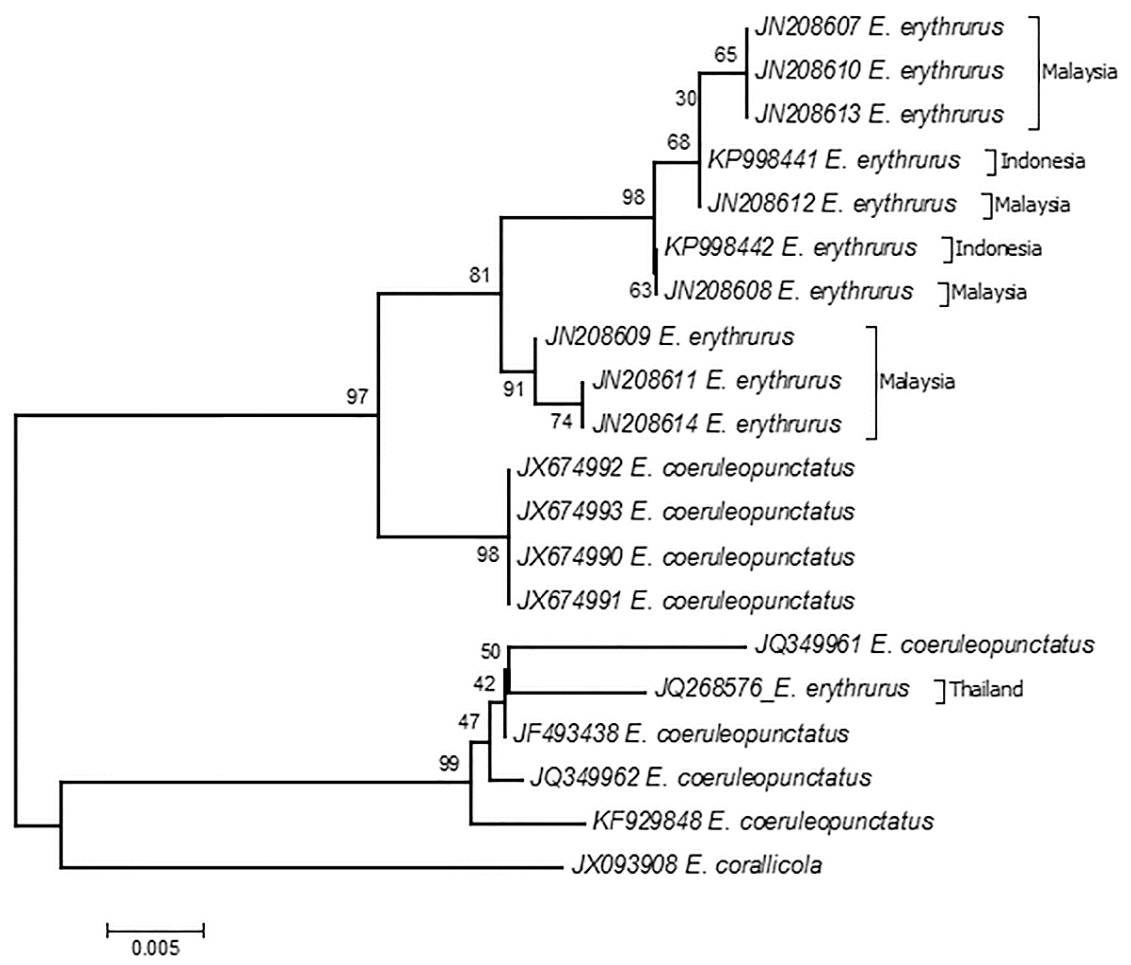

Figure 3. Neighbor-joining tree based on the $\mathrm{CO} 1$ nucleotide sequences of the E. erythrurus specimens analyzed in the present work and of species from GenBank (with Thai E. erythrurus). The numbers at the nodes indicate bootstrap values for 1000 replicates 
The taxonomic classification of the cloudy grouper, $E$. erythrurus (Valenciennes 1828) is class Pisces, subclass Osteichthyes (bony fishes), order Perciformes (perch-like fishes), family Serranidae (sea basses and groupers) and subfamily Epinephelinae (grouper). This species is a minor commercial importance fish (Heemstra and Randall 1993), most often caught with other grouper species. These species inhabit harbors and estuaries with muddy or siltysand bottoms, but nothing has been published on its biology. Geographical distribution of this species is known from Pakistan, India, Laccadive Island, Sri Lanka, the Gulf of Thailand, Indonesia, Singapore, Borneo and the Malaysian Peninsula (Heemstra and Randall 1993; Carpenter and Niem 1999; Allen et al. 2003). Based on the FishBase database, E.erythrurus was recorded in Indonesia from Sulawesi to Java. In museums, we identified RMNH 13525 (Java, Batavia), RMNH 13524 (Surabaya market), SU 61470 (Sangi Island), FMNH 22515-17 (Borneo, Kalimantan, Balikpapan Harbour), AMS I.19355-039 (Sabah, Sandakan Island), USNM 183241 (North Borneo) and FMNH 51717. In 2003, Allen and Adrim stated that the distribution of the species in Indonesia stretched from Sulawesi to Sumatra, and specimens were stored in the Western Australia Museum. In Thailand, these species were recorded in a preliminary checklist of coral reef fishes of the Gulf of Thailand (Satapoomin 2000) and also for the first karyological analysis and chromosomal characteristics of NORs research (Pinthong et al. 2015). Hegde et al. (2013) reported that these species included in the list of the new record along with their habitats from Goa, West coast of India. Sluka (2013) also stated that E. erythrurus was recorded in the three locations in near-shore rocky or corral habitats of western India. The report on this species can be used to supplement the Data Deficient (DD) status in the International Union for Conservation of Nature and Natural Resources (IUCN) Red List.

The samples in the present study originated from Bojongsalawe Beach (743'8.31'S 108 30'11.59'E) in the Pangandaran District of West Java, Indonesia. The shoreline of Bojongsalawe Beach directly faces the Indian Ocean. Due to the lack of report, based on IUCN Red List (2015), the species was categorized as "Data Deficient" (DD) status. To the light sight, based on the 2018 assessment data, the current status of this species categorized as Least Concern (LC) for the IUCN Red List (Russell 2018). A least concern (LC) species is a species which has been categorized by the IUCN as evaluated but not qualified for any other category. They do not qualify as threatened, near threatened, or (before 2001) conservation dependent. The significant result from this research is that the barcode sequence for Indonesian E. erythrurus, which was previously absent from GenBank, is presented here for the first time. The DNA analysis based on partial mitochondrial CO1 gene sequencing successfully identified and confirmed E. erythrurus juveniles; these DNA sequences have been submitted individually to GenBank. Partial sequencing of the mitochondrial CO1 gene may be used in rapid analyses for commercial species purposes, especially species identification at various developmental stages.

\section{ACKNOWLEDGMENTS}

We thank I. Hikmawan for contributing samples of juvenile Epinephelus erythrurus from Bojongsalawe, Pangandaran District, Indonesia.

\section{REFERENCES}

Allen GR, Adrim M. 2003. Coral reef fishes of Indonesia. Zool Stud 42 (1): $1-72$

Allen G, Steene R, Humann P, DeLoach N. 2003. Reef fish identification Tropical Pacific. New World Publication Inc. Singapore.

Barber P, Boyce SL. 2006. Estimating diversity of Indo-Pacific coral reef stomatopods through DNA barcoding of stomatopod larvae. Proc R Soc Lond B. 273: 2053-2061.

Byun SO, Fang Q, Zhou H, Hickford JGH. 2009. An effective method for silver staining DNA in large numbers of polyacrylamide gels. Anal Biochem 385: 174-175.

Carpenter KE, Niem VH. 1999. FAO Species identification guide for fishery purposes: The Living marine resources of the Western Central Pacific. Volume 4 Bony fishes part 2 (Mugillidae to Carangidae). FAO, Rome.

Craig MT, Pondella DJ, Franck JPC, Hafner JC. 2001. On the status of the serranid fish genus Epinephelus: evidence for paraphyly based upon 16S rDNA sequence. Mol Phylogenet Evol 19: 121-130.

Ding SX, Wang YH, Wang J, Zhuang X, Su YQ, You YZ, Li QF. 2006. Molecular phylogenetic relationships of 30 gruper species in China Seas based on 16S rDNA fragment sequences. Acta Zoologi Sinica 52 (3): 504-513.

Govindaraju GS, Jayasankar P. 2004. Taxonomic relationship among seven species of groupers (genus Epinephelus; family Serranidae) as revealed by RAPD fingerprinting. Mar Biotechnol 6: 229-237.

Hall TA. 1999. Bioedit: a user-friendly biological sequence alignment editor and analysis program for Windows 95/98/NT. Nucl Acids Symp Ser 4: 95-98.

Hebert PDN, Ratnasingham S, De Waard JR. 2003. Barcoding animal life: cytochrome c oxidase subunit 1 divergence among closely related species. Proc R Soc Lond B 270: 96-99.

Heemstra PC, Randall JE. 1993. FAO species catalogue: An annotated and illustrated catalogue of the grouper, rockcod, hind, coral grouper, and lyretail species known to date. Volume 16 Groupers of the world (Family Serranidae, subfamily Epinephelinae). Rome: FAO.

Hegde MR, Padate VP, Velip DT, Rivonker CU. 2013. An updated inventory of new records of coastal macrofauna along Goa, west coast of India. Indian J Geo Mar Sci 42 (7): 898-902.

Ivanova NV, Zemlak TS, Hanner RH, Hebert PDN. 2007. Universal primer cocktails for fish DNA barcoding. Mol Ecol Notes7: 544548.

Kimura M. 1980. A simple method for estimating evolutionary rate of base substitutions trough comparative studies of nucleotide sequences. J Mol Evol16: 111-120.

Noitkr K, Chaveerach A, Pinthong K, Tanomtong A, Sudmoon R, Tanee T. 2013.RAPD and barcode analyses of groupers of the genus Epinephelus. Gen Mol Res 12 (4): 5721-5732.

Pinthong K, Maneechot N, Tanomtong A, Supiwong W, Chanaboon T, Jangsuwan N. 2015. The first karyological analysis and chromosomal characteristics of NORs of the cloudy grouper, Epinephelus erythrurus (Perciformes, Epinephelinae) in Thailand. Cytologia 80(3): 279-286.

Randall JE, Heemstra PC. 1991. Revision of Indo-Pacific groupers (Perciformes: Serranidae: Epinephelinae), with descriptions of five new species. Indo-Pacific Fishes, Bishop Museum, Honolulu.

Russell B. 2018. Epinephelus erythrurus. The IUCN Red List of Threatened Species 2018: e.T132785A100534100. DOI: 10.2305/IUCN.UK.2018-2.RLTS.T132785A100534100.en. 
Sachithanandam V, Mohan PM, Chaaithanya IK, Dhivya P, Baskara R. 2012. DNA barcoding, phylogenetic study of Epinephelus spp. from Andaman coastal region, India. Indian J Geo Mar Sci 41(3): 203-211.

Satapoomin U. 2000. A preliminary checklist of coral reef fishes of the Gulf of Thailand, South China Sea. Raffles B Zool 48 (1): 31-53.

Sluka RD. 2013. Coastal marine fish biodiversity along the Western coast of India. J Threat Taxa 5(1): 3574-3579.

Tamura K, Peterson D, Peterson N, Stecher G, Filipski A, Kumar S. 2013. MEGA6: Molecular evolutionary genetics analysis version 6. Mol Biol Evol 30 (12): 2725-2729.
Teletchea F. 2009. Molecular identification methods of fish species: reassessment and possible applications. Rev Fish Biol Fisher 19: 265293.

Ward RD, Zemlak TS, Innes BH, Last PR, Hebert PD. 2005. DNA Barcoding of Australia's fish species. Phil Trans R Soc B 360: 18471857.

Wong EHK, Hanner RH. 2008. DNA barcoding detects market substitution in North American seafood. Food Res Int 41: 828-837. 